\title{
KLAUZULA DOTYCZĄCA PRZEDMIOTU UMOWY NAJMU W JĘZYKU KOREAŃSKIM I POLSKIM W ASPEKCIE TRANSLACYJNYM
}

\author{
Emilia WOJTASIK, mgr \\ Instytut Językoznawstwa, Wydział Neofilologii \\ Uniwersytet im. A. Mickiewicza \\ al. Niepodległości 4, 61-874 Poznań, Poland \\ ewojtasik@yahoo.com
}

\begin{abstract}
Abstrakt: Artykuł skupia się na wstępnej analizie porównawczej kluczowych klauzul w umowach cywilnych prawa koreańskiego i polskiego na przykładzie klauzuli przedmiotu umowy najmu. Analiza jest dokonywana $\mathrm{w}$ oparciu m.in. o stosowaną $\mathrm{w}$ przekładzie prawniczym metodę przekładu pragmatycznego Kierzkowskiej (2002), skoposu Vermeera oraz o teksty paralelne. Właściwą analizę poprzedza krótki wstęp poświęcony systemom prawnym Polski i Korei Południowej, przedstawiony jako kompromis, wypracowany w obliczu konieczności pogodzenia tradycji i sprostania wymogom globalizacji i postępu cywilizacyjnego. Główna część artykułu skupia się na analizie klauzuli przedmiotu najmu w umowie najmu, począwszy od jego wskazania przez opis i charakterystykę specyfiki danego przedmiotu umowy aż po warunki przekazania lub zwrotu tegoż przedmiotu stronie wynajmującej. Artykuł poprzez analizę języka prawnego i prawniczego wykorzystywanego w klauzuli przedmiotu najmu w kontekście translacyjnym stanowi próbę zwrócenia uwagi na wagę osadzenia przekładu w rzeczywistościach prawnych. Uczula także na zagadnienia gramatyczno-leksykalne w przekładzie szczególnie w parze językowej j.polski-j.koreański.

Słowa kluczowe: klauzula przedmiotu najmu w umowie najmu, koreańskie prawo cywilne, polskie prawo cywilne, aspekt translacyjny, analiza porównawcza języka prawniczego i prawa, teksty paralelne
\end{abstract}

\section{KOREAN AND POLISH CLAUSES OF LEASE OBJECTS IN TRANSLATION}

Abstract: The article focuses on a preliminary comparative analysis of clauses of lease objects in civil contracts of Korean and Polish law. The research methods include Kierzkowska's pragmatic translation model (2002) as well as Vermeer's model of skopos and the comparison parallel texts. The analysis is preceded by a short introduction on the legal systems of the Republic of Poland and the Republic of South Korea, presented as a kind of compromise worked out in the need to reconcile tradition and meeting the requirements of globalization along with the progress of civilization. The main part of the article analyzes the translation of the lease object clause in the lease contract, starting from its description and characteristics of the contract objects through pointing out the terms and conditions of transfer or return of the lease object to the tenant. The article aims at pointing presenting the analysis of legal language used in the pertinent contract clause in translation context. It also presents grammatical and lexical issues typical in PolishKorean translation.

Key words: clause of lease objects in a lease contract, Korean civil law, Polish civil law, aspect of translation, comparative analysis of language of law, parallel texts 


\title{
한국어와 폴란드어에서 번역 중심으로 임대계약의 임대목적물 조항 분석
}

\begin{abstract}
Abstrakt: 본 연구는 한국과 폴란드 민사법에서 임대계약의 목적물 조항을 예비비교 분석에 초점을 맞추고 있다. 본 연구는 Kierzkowska 의 번역 실용이류모델, Vermeer 의 스코포스 이론 및 병렬말뭉치 3 개 개념으로 분석을 해 본다. 분석은 현재법시스템이라면 전통을 조정하고 문명의 발전과 함께 세계화의 필요로서 조건을 충족시킨다는 것으로 폴란드와 한국 법시스템 비교를 간단하게 해본다. 연구 골자는 번역 중심으로 임대계약의 목적물 조항에서 법령용어와 법률어를 분석하는 것이다. 임대계약목적물 묘사부터 시작해서 계약의 조건과 임대목적물 반출조건까지 연구한다. 본 연구의 목적은 법령용어와 법률어로 법시스템에 들어가 있는 현실과 번역에 관심을 끌이는 것이다. 또한, 본 연구는 특히 한-폴 번역에 나오는 문법과 어휘 문제를 알려 준다.

키워드: 임대차계약의 임대차 목적물 조항, 한국 민사법, 폴란드 민사법, 통번역중심, 법령용어 및 법률어 비교 연구, 병렬말뭉치
\end{abstract}

\section{Wstęp}

Celem niniejszego artykułu jest przybliżenie problemów związanych z przekładem przedmiotu umowy najmu $\mathrm{w}$ umowach prawa cywilnego $\mathrm{w}$ językach koreańskim i polskim.

Wydawać się może, że nie ma zapotrzebowania na takie zestawienie przekładu umów polsko-koreańskich, jednak jest to założenie błędne - wystarczy rozejrzeć się wokół by zauważyć rosnący odsetek udziału Koreańczyków w Polsce. Ta obecność spowodowana jest wieloma różnymi czynnikami, od tak często podnoszonego czynnika piękna polskiej kultury ${ }^{1}$, przez politykę i historię ${ }^{2}$ aż do ekonomii ${ }^{3}$. Co za tym idzie, pojawia się konieczność funkcjonowania w nowej rzeczywistości - a gdzie rzeczywistość, tam i prawo, systematyzujące codzienne funkcjonowanie w społeczeństwie i świecie. Obecnie kwestia tłumaczeń prawnych i prawniczych w parze językowej polski-koreański jest bardzo nowa i do tej pory nie ma wielu opracowań z tego zakresu. Stąd pomysł powstania takiego opracowania.

Za materiał badawczy, stanowiący podłoże dla poniższej pracy, przyjęto koreańskie i polskie umowy najmu, przy czym należy zaznaczyć, że głównym kryterium, według którego teksty były analizowane, są klauzule. Zanalizowano w tym celu typowe klauzule oznaczające przedmiot umowy zawarte w umowach sporządzonych na podstawie koreańskiego i polskiego kodeksu cywilnego, dokonując ich porównania i tłumaczenia. W artykule oparto się na metodzie transkrypcji języka koreańskiego zgodnie z zasadą McCune'a-Reischauera z 1937 r. a zmodyfikowaną i ulepszoną w roku 2000 .

\footnotetext{
${ }^{1}$ Koreańczycy zapytani o to, skąd wzięło się ich zainteresowanie Polską, wskazują jako główną determinantę kulturę polską wyrażaną muzyką Chopina lub filmami Wajdy i Kieślowskiego.

${ }^{2}$ Czołowe postaci polityczne znane w Korei to przede wszystkim Lech Wałęsa, z historycznych najczęściej wymieniana jest Maria Curie-Skłodowska.

${ }^{3} \mathrm{Na}$ przestrzeni ostatnich lat daje się zauważyć znaczny wzrost inwestycji gospodarczych poczynionych przez wielkie przedsiębiorstwa koreańskie - np. Samsung, LG. 146
} 


\section{Comparative Legilinguistics 17/2014}

Dla potrzeb tej pracy przyjęto metodę badawczą porównania tekstów paralelnych. Teksty paralelne to nie tylko dokumenty, to przede wszystkim niezgłębione źródło wiedzy językowej dla tłumacza tekstów prawniczych. Pisze o tym m.in. Kierzkowska (2002:56), ujmując sedno tych tekstów jako ,źródło poprawnej frazeologii i środków stylistycznych danego języka prawnego lub prawniczego oraz właściwej dla języka tego terminologii, która również może mieć zastosowanie przy tłumaczeniu na język właściwy dla innego systemu prawnego". O ich znaczeniu oraz szerokim spectrum zastosowania wiedzą nie tylko teoretycy ale przede wszystkim praktycy przekładu prawnego i prawniczego (por. Kubacki 2013, Kielar 1991, Kierzkowska 2002 itp.)

Oparto się także na założeniach metody przekładu pragmatycznego (Kierzkowska 2002), wyrosłego z założeń teorii skoposu Vermeera. Znaczenie skoposu podkreśla np. Sandrini (1996), ujmując tę zależność w kategoriach relacji zależności między celem a tłumaczeniem. Zgodnie z twierdzeniem Reiss (1971), osoba podejmująca się przekładu pragmatycznego, winna skupić się na cechach niejęzykowych tzn. tematyka, dziedzina, cel, otoczenie kulturowe i rzeczywistość, do których dany tekst trafi.

\section{Rzeczywistości prawne Republiki Korei i Rzeczpospolitej Polskiej w zarysie}

Republika Korei Południowej jest państwem, w którym obowiązujący obecnie system prawny jest $\mathrm{z}$ jednej strony wynikową a $\mathrm{z}$ drugiej - kompromisem pomiędzy koniecznością znalezienia miejsca we współczesnym, zglobalizowanym świecie a chęcią $\mathrm{i}$ obowiązkiem zachowania rysu tradycyjnego. Koreański system to $\mathrm{w}$ rezultacie połączenie konfucjańskich zasad, chińskiego dawnego prawa zmodyfikowanego i przystosowanego na przestrzeni wieków do realiów koreańskich, elementów systemu japońskiego zaimplementowanego w okresie okupacji japońskiej 1905-1945 i wpływów współczesnych w postaci elementów systemu amerykańskiego. Dobitniej wskazuje to choćby Kim Kipyo (2013:3), mówiąc, że:

„Korean society maintained its own traditional legal system until the modern judicial system was introduced to Korea at the end of the Joseon Dynasty in the nineteenth century. Korea adopted modern legal system at the end of the nineteenth century and in the beginning of the twentieth century (...) it introduced the concepts of Western legal system"

Elementy prawa amerykańskiego zostały wprowadzone po zmodyfkowaniu stosunkowo niedawno i zostało to wymuszone postępem cywilizacyjnym oraz nawiązaniem kontaktów handlowych. Republika Korei Południowej opiera zatem swój system prawny na Konstytucji z 17 lipca 1948, która została poddana do tej pory dziewięć razy ${ }^{4}$ poprawkom, ustawach oraz innych aktach prawnych wydawanych przez właściwe organy. Praktycy i teoretycy prawa podkreślają znaczenie elementów tradycyjnych w systemie prawnym Korei Południowej jednocześnie uwypuklając różnice między Azją a resztą świata, zaznaczając za Hahmem (1967 i nast.: 6), który odniósł się do aspektu prawnego polityki, że: "If one could characterise the Western political tradition as legalistic, the Eastern political tradition could be characterized as ethical".

Polski system prawny jest także wynikową cech systemów praw europejskich, głównie niemieckiego oraz francuskiego. Miało to swój skutek w obecnym kształcie

\footnotetext{
${ }^{4}$ Stan na 22.12.2013r.
} 
Emilia Wojtasik, Klauzula dotyczaca przedmiotu umowy najmu...

systemu, charakterystycznym dla typu kontynentalnego. Na przestrzeni wieków oraz w wyniku zmian historyczno-politycznych w Polsce właściwa gałąź prawa obowiązywała w zależności od położenia geograficznego oraz rozpatrywanej sprawy. Wspomina o tym Radwański (2005: 20), podkreślając, że ,na terytorium objętym granicami Polski odrodzonej po I Wojnie Światowej obowiązywały różne systemy prawa cywilnego, przeważnie pochodzenia obcego". Radwański wymienia główne systemy prawa, a więc Kodeks Napoleona z 1804r., Kodeks Cywilny Królestwa Polskiego z 1825r., rosyjskie prawo cywilne, niemiecki Kodeks Cywilny z 1896r. oraz austriacki Kodeks Cywilny z 1811r. W związku z tak licznymi systemami prawa, które obowiązywały w danym okresie na terytorium kraju, system polski musiał przejść najpierw proces spisywania a potem ujednolicania. Po okresie komunizmu i przemianach ustrojowych roku 1989, w obecnym kształcie polskiego systemu prawnego najważniejszym aktem prawnym jest Konstytucja RP z 1997 roku, po której hierarchicznie ważne są odpowiednio ustawy zwykłe, umowy międzynarodowe, rozporządzenia i akty prawa miejscowego (Redelbach 2002: 193-196). Artykuł ten odnosić się będzie do obowiązujących na dzień 22.12.2013r. przepisów polskiego i koreańskiego Kodeksu Cywilnego.

\section{Interdyscyplinarność tłumaczenia prawniczego.}

Tłumaczenie prawne i prawnicze to dziedzina wykazująca się wysokim poziomem interdyscyplinarności. Należy bowiem rozpatrywać ją w przynajmniej czterech, jeśli nie więcej, aspektach: językowym i językoznawczym, translatologicznym, prawnym i kulturowym. Kryterium językowe i językoznawcze jest w opinii autorki znaczące, gdyż znajomość zagadnień lingwistycznych jest niezwykle ważna dla jakiegokolwiek przekładu. Translatologia to kolejna dziedzina, rzutująca na sam proces przekładu także doborem metody i strategii tłumaczeniowej. Aspekt prawny ważny jest ze względu na przeniesienie tłumaczenia na dziedzinę stanowiącą ważne tło pracy, determinujący nie tylko wykorzystywany zasób leksykalny, ale także sposób pracy. Na koniec kultura ujmowana jako czynnik stanowiący o wadze zrozumienia w procesie komunikacyjnym choć również mający niemały wpływ na cały przekaz niewerbalny towarzyszący przekładom ustnym. Stąd, jak sugeruje Reiss (1971: 56) należy wziąć pod uwagę także inne czynniki powiązane $\mathrm{z}$ tekstem $\mathrm{w}$ sposób mniej bezpośredni, a więc jego pochodzenie, role tekstu i odbiorcy. Dlatego też kluczowe są nie tylko cechy ściśle językowe (a więc semantyka, składnia, gramatyka i stylistyka), ale także wszystkie czynniki okalające język, które końcowo składają się na pragmatyczną i językową ocenę przekładu.

\section{Klauzula dotycząca przedmiotu umowy w języku polskim i koreańskim}

W treści umów zawartych w oparciu o ogólne przepisy poświęcone zobowiązaniom umownym uwzględnia się szereg klauzul, precyzujących ustalenia pomiędzy stronami. Wśród tych klauzul występuje klauzula przedmiotu umowy.

W umowach koreańskich najczęściej przedmiot umowy zostaje wprowadzony w pierwszym paragrafie (zaraz po nagłówku, dacie i miejscu sporządzenia umowy oraz oznaczeniu stron umowy) i jest on często sygnalizowany terminami cel umowy -계약의 


\section{Comparative Legilinguistics 17/2014}

목적[gyeyag-ui mogjeog] bądź oznaczenie docelowego przedmiotu najmu 임대차목적물의 표시 [imdaechamogjeogmul-ui pyosi], lit. oznaczenie celu przedmiotu najmu. Zdarzają się przypadki umów, w których cel zostaje wprowadzony bez wyodrębnionego wprowadzenia na początku paragrafu.

Poszczególne paragrafy bądź artykuły w treści umowy mogą być numerowane, nie ma jednak takiego obowiązku. Jeśli natomiast w umowie zostaje podany numer paragrafu, to podczas odczytywania na głos ten liczebnik jest podawany w systemie sinokoreańskim ${ }^{5}$.

()제 1 조 (계약의 목적) 본 계약은 갑이 을에 게 본 계약에 따른 장비(이하 "본 장비"라 한다)를 임대하고 을이 이를 임차하는 임대차계약에 필요한 제반사항과 갑과 을간의 권리의 무관계를 규정함을 목적으로 한다.

[jae 1 jo. (gyeyag-ui mogjeog). Pon kyeyageun kabi eurege pon gyeyage ttareun jangbi (iha pon jangbi'ra handa)reul imdaehago euri ireul imchahaneun imdaechagyeyage piryuhan jebansahanggwa gapgwa eulgan-ui kwolliuimugwangyereul gyujeongham-eul mogjeog-euro handa]

[Tłum. lit.: Artykuł 1. (Cel umowy) Przedstawiona umowa przyjmuje za cel ustalenie wszystkich potrzebnych spraw oraz relacje praw i obowiązków między A i B zgodnie z umową najmu/dzierżawy gdzie A wynajmuje/dzierżawi B zgodne $\mathrm{Z}$ przedstawioną umową urządzenie (nazywane niżej ,przedstawionym urządzeniem") a B je najmuje/wydzierżawia]

[TLOT: $\S 1$. (Cel umowy) poniższa umowa ma na celu ustalenie wszystkich kwestii niezbędnych do zawarcia umowy najmu oraz ustalenia relacji prawnych i obowiązków między Wynajmującym a Najemcą, niezbędnych do zawiązania umowy najmu tego urządzenia, gdzie Wynajmujący wynajmuje Najemcy urządzenie (dalej nazywane „Niniejsze urządzenie”) zgodnie z poniższą umową.]

() 제 2 조 (임대의 목적물) 본 계약에 따라 을이 임대하는 장비는 다음과 같으며, 그 외 장비와 관한 구체적인 사항은 갑과 을간의 별도의 합의로서 정한다.

[je 2 jo (imdaeui mogjeogmul) pon gyeyage ttara euri imdaehaneun jangbineun daeumgwa kateumyeo, keu wui jangbiwa kwanhan kuchaejogin sahangeun Kapgwa Eulganui pyeoldoui habuiroseo jeonghanda.

[Tłum. literalne: art. 2 (Przedmiot celu najmu) Zgodnie z przedstawioną umową wynajmowane przez B urządzenie jest jak podane poniżej, poza wymienionymi dokładne kwestie związane z urządzeniem ustalają między sobą A i B podczas oddzielnych ustaleń]

TLOT: (Przedmiot najmu/docelowy przedmiot najmu) zgodnie z poniższą umową, urządzenie wynajmowane przez Najemcę jest zgodne z tym, co poniżej. Wszystkie dokładne kwestie dotyczące urządzenia są regulowane odrębnym(i) porozumieniem/ ustaleniami.

\footnotetext{
${ }^{5} \mathrm{~W}$ języku koreańskim funkcjonują dwa systemy liczebników - zapożyczone z języka chińskiego (tzw. sino-koreańskie) i rodzime. Dobór właściwego systemu następuje w oparciu o klasyfikację rzeczownika, do którego liczebnik ma się odnosić. Determinantą doboru systemu liczebnika jest klasyfikacja rzeczownika (rodzimy lub zapożyczony) oraz odpowiadający danym grupom klasyfikator. Por. Sohn Ho-Min (2001:204-206, 208)
} 
Emilia Wojtasik, Klauzula dotyczaca przedmiotu umowy najmu...

Zaobserwowany szyk zdaniowy jest odzwierciedleniem specyfiki koreańskiej gramatyki. Wprowadzony na początku podmiot główny ma swoje bezpośrednie odniesienie do głównego celu zaznaczonego na samym końcu zdania. Treść odnosząca się do praw i zobowiązań wynikających z zawieranej umowy zostaje wpleciona w środek zdania. Stosowane konstrukcje gramatyczne to najczęściej zdania współrzędnie lub podrzędnie złożone (w przytoczonym przykładzie - dopełnieniowe). Najczęściej cel umowy w treści jest ujęty czasownikami w trybie oznajmującym, czasie teraźniejszym, liczbie pojedynczej lub mnogiej (zwykle jednak nie ma takiego rozróżnienia) ${ }^{6}$. Zwrócić należy uwagę na zastosowanie w oryginale w przytoczonych przykładach słowa umowa w podmiocie odnoszącego się nie do dokumentu a raczej ustaleń czy też porozumienia między stronami. Wskazuje na to brak wywodzącego się z języka chińskiego przyrostka 서 [seo, 青] a oznaczającego dokument. Z kolei relacja zdawczo-odbiorcza ktoś komuś (dla kogoś) wyraża się zaimkami osobowymi: -이 -에게 [i--ege]. Zauważyć daje się wykorzystanie łączników rzeczownikowych 와/과 [wa/gwa] - i. Zastosowano także zestawienia czasownik deskryptywny ${ }^{7}$ w formie przymiotnikowej + rzeczownik + rzeczownik, np. 필요한 제반 사항 [piryuhan jeban sahang] - potrzebny /niezbędny stan.

Podkreśla się bardzo często zgodność przedmiotu umowy $\mathrm{z}$ dokonanymi ustaleniami poprzez zastosowanie form pochodnych od czasownika 따르다 [ddareuda]tu w znaczeniu stosować się do, słów, zgodnie z, wedtug - 따라 [ddara] bezosobowo lub $\mathrm{w}$ odmianie 따른 [ddareun] w zależności od określanej części zdania ${ }^{8}$, np. 따른 장비[ttareun jangbi] - urzadzenie zgodne/wspomniane (domyślnie: $z$ ustaleniami/specyfikacja). Wymieniając natomiast poszczególne cechy charakterystyczne a stanowiące o urządzeniu, do których należy się odnieść, korzysta się z frazy: 다음과 같다 [daeumgwa gatta] - takie jak ponizej, gdzie 다음[daeum] oznacza następne, potem, a -과 같다 to konstrukcja gramatyczna spójnik + czasownik, oznaczająca być takim samym z (czymś/kimś). Ostatni czasownik 같다[gatta] - być takim samym może być $\mathrm{z}$ kolei łączony $\mathrm{z}$ innymi konstrukcjami gramatycznymi, np. konstrukcją zdania współrzędnie złożonego: 다음과 같으며 [daeumgwa gateumyeo] jest takie same jak poniżej $i$. Przez zestawienie: przymiotnik odczasownikowy (utworzony tutaj od czasownika aktywnego) + rzeczownik 임대하는 장비 [imdaehaneun jangbi] - wynajmowane urządzenie, podkreślono bezpośrednie odniesienie stosunku

\footnotetext{
${ }^{6}$ Język koreański pozwala na stosowanie takiej samej formy gramatycznej czasownika bez względu na liczbę, w jakiej jest wyrażany podmiot. Te części zdania nie wywierają na siebie wpływu koniugacyjnego.

${ }^{7}$ Sohn (2001:209) precyzuje, że: "predicates (verbs and adjectives) are different from all other categories in that they must inflect. Unlike in English, an adjective inflects in the same way as a verb without the help of copula (...) however, there are morphological, syntactic, and semantic differences to warrant two separate categories". Z kolei Im, Ho-Bin (2001:97) podaje, że: "There are two main types of verb in Korean: action and descriptive. Action verbs denote actions, activities, motions or processes. Descriptive verbs (also called 'adjectives') denote qualities or states." W treści tego artykułu przyjmę rozróżnienie na czasowniki aktywne i deskryptywne zgodnie z poglądem Im, Ho-Bina.

8 W j. koreańskim czasowniki deskryptywne przed rzeczownikami przyjmują formę przymiotnikową.

150
} 
najmu do konkretnego przedmiotu. Inne związki przytoczone w powyższym przykładzie oparte na podobnym zestawieniu to: 구체적인 사항 [guchejeogin sahang] konkretne/dokładne kwestie. Kolejna $\mathrm{z}$ wykorzystanych fraz to osobowa teraźniejsza forma czasownika ustalać coś $w$ drodze porozumienia - 합의로서 정하다, gdzie wykorzystano konstrukcję gramatyczną -로서 $[\text { roseo }]^{9}$ - jako coś/ktoś, poprzez bycie czymś/kimś typową dla urzędowego i pisemnego stylu wypowiedzi.

Umowy polskie mają najczęściej bardzo prosto podany przedmiot umowy przy wykorzystaniu następujących zdań:

() $\S 1$.

Przedmiot umowy

SLOT: 임대의 목적물

[imdae-ui mogjeogmul]

[Przedmiot umowy]

() Przedmiotem umowy jest ...

SLOT: 임대의 목적물은 ...

[imdae-ui mogjeogmul-eun....]

[Przedmiot umowy to...]

Fraza przedmiot umowy zostaje więc ujęta zazwyczaj w funkcji podmiotu. Zasadniczo ta klauzula umowna ma formę definicji gdzie przedmiot umowy to definiens, łącznikiem (zwrot łączący) jest zazwyczaj czasownik być w trzeciej osobie liczby pojedynczej (jest), a definiendum jest wyliczeniem elementów składających się na znaczenie w jakim termin przedmiot umowy będzie używany w dalszej części umowy. Definiendum może być określone przy użyciu rzeczowników i zestawień rzeczownikowych, np. wynajem, świadczenie ustug, dystrybucja towarów Zleceniodawcy, ale może mieć także formę opisową.

() Przedmiotem umowy zgodnie z pismem - zamówieniem „Najemcy” jest wynajem przez „Wynajmującego" ...

SLOT:계약서에 따라 임대인이 임차인 주문서류로 인차인에게 임대의 목적물은 $[\cdots]$ 임배하는 것이다.

[gyeyagseo-e ttara imdaeini imchain jumunseoryuro imchain-ege imdaeui mogjeogmul-eun .......imdaehaneun geosida].

Można także spotkać się z zapisem wskazującym przedmiot umowy w sposób niebezpośredni, a więc odwołującym się do czynności umowy przeprowadzanej na konkretnym przedmiocie kontraktu.

() Wynajmujący oddaje Najemcy w najem pomieszczenia produkcyjne w budynku określonym w $§ 1$ o łącznej powierzchni ... $\mathrm{m}^{2}$, zgodne $\mathrm{z}$ załączonym szkicem sytuacyjnym.

SLOT: 임대인은 임차인에게 제 1 조에 정한 건물에 있는 면적합계로 ... m2 되는 첨부 된 도면에 따른 생산 시설을 임대한다.

\footnotetext{
${ }^{9}$ Pisze o tym m.in Im, Ho-Bin (2001: 157), ujmując tę konstrukcję jako partykułę dołączaną do rzeczowników opisujących status, pojemność, pozycję lub kwalifikacje.
} 
Emilia Wojtasik, Klauzula dotyczaca przedmiotu umowy najmu...

[imdaeineun imchain-ege jae 1 joe jeonghan geonmule ittneun myeongjeoghapgyero .... $\mathrm{m} 2$ dweneun cheombudwen domyeone ttareun saengsan siseoreul imhanda].

Przedmiot umowy może być więc ujęty na różne sposoby: poprzez ogólne wskazanie, np. najem, dzierżawa + obiekt (np. oddaje $w$ najem pomieszczenia), bądź szczegółowe opisanie cech pozwalających na szybką i precyzyjną identyfikację, np.

() ciężkich maszyn budowlanych i pojazdów, do zatrudnienia i rozliczenia w systemie pracy czasowym

SLOT: ( ) 중건설 기계 및 차량, 근로시간 시스템으로 고용과 결제...

[jung-geonseol gigye mich chalyang, geunmu siseutem-eulo goyong-gwa gyeolje...]

Może być to numerowany paragrafami fragment tekstu $\mathrm{z}$ zawartymi odniesieniami do uprzednio podanych informacji jednak nie jest to wymóg konieczny. Nie można jednak zaprzeczyć, że takie odniesienie jeszcze bardziej precyzuje przedmiot transakcji i tym samym przekłada się na mniejsze ryzyko popełnienia błędu bądź niezrozumienia. Jest to także przydatne dla tłumacza, ponieważ rozjaśnia to obraz tekstu w przypadku zastosowania w oryginale zawiłych bądź niejasnych sformułowań.

() 2. Lokal mieszkalny, o którym mowa w ustępie pierwszym składa się z ... (liczba i rodzaj pomieszczeń). Łączna powierzchnia użytkowa lokalu wynosi ... $\mathrm{m}^{2}$.

SLOT: 2. 1 조에 따른 주거(실 종류와 수)는 .....이다. 주거 면적은 $\mathrm{m} 2$ 이다.

[2. 1jo-e ttaleun jugeoneun (sil jonglyuwa su)ida. jugeo myeonjeog-eun $\mathrm{m} 2$ ida.]

W przypadku najmu urządzeń, w tym miejscu umowy znajdzie się specyfikacja urządzenia wraz ze szczegółowym opisem jego stanu technicznego itp.

Zauważyć można, że wykorzystywane są tutaj frazy i kolokacje odnoszące się do zawieralności, np. lokal składa się, jak i do całościowego ujęcia mniejszej części w większej, np. lokal ale rodzaj pomieszczeń. Występuje także rozbudowywanie opisu rzeczowników przy pomocy przymiotników przy jednoczesnej gradacji ich zakresu oraz charakterystyki cech, np. taczna powierzchnia użtkowa, i ich dalsze odnoszenie do rozpatrywanej części zdania, np. do dopełnienia bliższego, np. powierzchnia użytkowa lokalu. W kontekście podawanego metrażu często występuje czasownik wynosić w relacji do obszaru w dostosowanej do rozpatrywanego rzeczownika, jego rodzaju oraz liczby osobowej formie czasownika, np. powierzchnia wynosi.

W języku polskim w przypadku umów najmu pomieszczeń w tej części umowy podaje się rodzaj pomieszczenia (lokal, lokal użytkowy, lokal mieszkalny, lokal usługowy, mieszkanie), jego obszar, liczbę wydzielonych w nim pomieszczeń a także łączną powierzchnię użytkową. Te elementy podawane są w oparciu o obowiązujący w Polsce system miar $\left(\mathrm{m}^{2}\right)$.

W języku koreańskim charakterystyka przedmiotu umowy najmu może być ujmowana na przykład w sposób następujący: 
() [임대차목적물의 표시]

소재지: ... 시 ... 구 ... 동 ... 번지

...층 (...)호 용 도: (...) 업 종: (...)

\begin{tabular}{|c|r|r|r|}
\hline \multirow{2}{*}{$\begin{array}{c}\text { 임대 점포 } \\
\text { 면적 }\end{array}$} & 전 용 면 적 & 공 용 면 적 & 면 적 합 계 \\
\cline { 2 - 4 } & $\mathrm{m} 2$ & $\mathrm{~m} 2$ & $\mathrm{~m} 2$ \\
\hline
\end{tabular}

[() [imdaecha mogjokmur-ui pyosi]

sojaeji: ... si ... gu ... dong ... peonji

(...) chong (...)ho ... yongdo: (...) eopjong: (...)

\begin{tabular}{|c|c|c|c|}
\hline \multirow{2}{*}{$\begin{array}{c}\text { Imdae jeompo } \\
\text { myeonjeog }\end{array}$} & Jeonyong myeonjeog & Gongyong myeonjeog & $\begin{array}{c}\text { Myeonjeog } \\
\text { hapgye }\end{array}$ \\
\cline { 2 - 4 } & $\mathrm{m} 2$ & $\mathrm{~m} 2$ & $\mathrm{~m} 2$ \\
\hline
\end{tabular}

[Tłum. literalne: Oznaczenie przedmiotu celu umowy najmu

Miejsce: miasto, dzielnica, osiedle, numer (budynku)

(...) piętro (...) numer (lokalu) ... zakres użycia: (...) rodzaj handlu: (...)

\begin{tabular}{|c|c|c|c|}
\hline \multirow{2}{*}{$\begin{array}{c}\text { Obszar } \\
\text { najmowanego } \\
\text { sklepu }\end{array}$} & $\begin{array}{c}\text { Obszar użytku } \\
\text { indywidualnego }\end{array}$ & $\begin{array}{c}\text { Obszar użytku } \\
\text { publicznego }\end{array}$ & $\begin{array}{c}\text { Obszar } \\
\text { razem }\end{array}$ \\
\cline { 2 - 4 } & $\mathrm{m} 2$ & $\mathrm{~m} 2$ & $\mathrm{~m} 2$ \\
\hline
\end{tabular}

[TLOT: oznaczenie przedmiotu docelowego najmu

Lokalizacja: miasto , dzielnica, osiedle numer

Piętro (...) numer (...) zastosowanie: (...) branża: (...)

\begin{tabular}{|c|c|c|c|}
\hline \multirow{2}{*}{$\begin{array}{c}\text { Obszar } \\
\text { najmowanej } \\
\text { powierzchni } \\
\text { sklepowej }\end{array}$} & $\begin{array}{c}\text { Obszar użytkowania } \\
\text { indywidualnego }\end{array}$ & Obszar wspólny & $\begin{array}{c}\text { Obszar } \\
\text { łącznie }\end{array}$ \\
\cline { 2 - 4 } & $\mathrm{m} 2$ & $\mathrm{~m} 2$ & $\mathrm{~m} 2$ \\
\hline
\end{tabular}

W przypadku adresu lokalu usługowego bądź innego bardzo często podaje się adres w szyku odmiennym niż ten wykorzystywany w Polsce. Ta kolejność w oryginale prezentuje się następująco: miasto - dzielnica - osiedle - numer domu - numer mieszkania/lokalu. Jest to mylące dla osób niezaznajomionych z tamtejszą strukturą adresu, stąd tak ważne jest, aby tłumacz posiadał także wiedzę z zakresu administracji.

$\mathrm{W}$ oryginalnym fragmencie dotyczącym lokalizacji występuje słowo 동 [dong], które często jest thumaczone jako „sąsiedztwo” lub „osiedle” ${ }^{10}$, uważam jednak, że

${ }^{10}$ Osiedle jest elementem administracyjnym w Korei Południowej używanym w związku z nagminnym brakiem nazewnictwa ulic $w$ mniejszych miejscowościach. W większych 
Emilia Wojtasik, Klauzula dotyczaca przedmiotu umowy nајти...

bardziej adekwatnym i bardziej uzasadnione ze względów stylistycznych i kulturowych jest korzystanie w tym miejscu ze słowa „osiedle”.

Jeśli chodzi o odniesienie do powierzchni, tutaj także problemem, na jaki natyka się tłumacz, jest ciągłe używanie w Korei Południowej innego systemu miary. W przytoczonych przykładach pojawia się już odniesienie do systemu obowiązującego także w Europie (metry kwadratowe), jednak wykorzystywane są także takie nazwy miar obowiązujące w Korei jak pyeong, która to miara w odniesieniu do powierzchni ${ }^{11}$ wynosi $3,3058 \mathrm{~m}^{2}$. Należy wówczas zwrócić także uwagę na różnice w zapisie formuł matematycznych: w Korei jednostki dziesiętne zapisuje się po kropce po rzędzie jedności, podczas gdy w Polsce używany jest w tym miejscu przecinek. W przekładzie konieczna jest lokalizacja zapisu przez przełożenie na system obowiązujący na danym obszarze językowym. Brak zmiany zapisu może prowadzić do zaburzeń komunikacyjnych, gdyż w systemie polskim kropka jest także używana jako separator dla tysięcy.

W tym fragmencie umowy wykorzystywane są zazwyczaj same rzeczowniki, bez odniesień do czasowników w ich formie osobowej. Rzeczowniki są natomiast albo pochodzenia rodzimego, bądź zapożyczone z chińskiego (wówczas są skrócone) lub innych języków. Zauważyć można zestawienia kilku rzeczowników (każdy $\mathrm{w}$ mianowniku), $\mathrm{z}$ których jeden pełni funkcję podmiotu a reszta przydawek (przymiotników odrzeczownikowych) np. 전용면적/공용면적 [jeon-yong-myeonjeog/gong-yong-myeon-jeog] - obszar użytku prywatnego/publicznego, ale także zestawienia dwóch rzeczowników, które stanowią o spójności frazy, np. 면적합계 [myeonjeog hapgye] - obszar tacznie, razem.

W tej części zawarte są więc te elementy, które dostarczają precyzyjnych informacji o przedmiocie umowy, np.

() 주택의 유형:

- 아파트:

- 연립주택:

- 다세대주택

- 다가구주택

- 단독주택

[jutaeg-ui yuhyeong:

- Apateu;

- Yeollipjutaeg

- Dasedaejutaeg;

- Dagagujutaeg;

- Dandogjutaeg;

[Tłum. literalne: typ domu:

- $\quad$ Mieszkanie (apt.)

miejscowościach spotyka się już nazwy ulic, jednak wydają się one mieć znaczenie bardziej komunikacyjne w transporcie niż jako element adresowy lokalu.

11 평 pyeong może odnosić się także do objętości i wówczas wynosi $6,013 \mathrm{~m}^{3}$.

154 
- $\quad$ Szereg domów;

- Dom z wieloma gospodarstwami;

- $\quad$ Dom z wieloma mieszkaniami;

- Oddzielnie stojący dom]

[TLOT: Typ domu:

- mieszkanie;

- $\quad$ dom w zabudowie szeregowej;

- dom wielorodzinny;

- $\quad$ dom wielorodzinny należący do jednego właściciela;

- $\quad$ dom wolnostojący]

Poszczególne dane odnoszą się do charakterystyki budynku oraz jego typu własności. Jak zauważamy, przedmiotem może być nie tylko jednostka wyodrębniona, czyli mieszkanie, ale także cały budynek. Przytoczone przykłady oprócz specyficznych właściwości klasyfikujących je jako dany podtyp, mają także ograniczenia techniczne, np. ilość pięter bądź informacja o własności i współwłasności. Oprócz słowa mieszkanie 아파트 [apateu], pozostałe przykłady zawierają słowo dom 주택 [jutaek] wraz z ich dalszą specyfikacją, np. 연립주택 [yeollib jutaek] - dom w zabudowie szeregowej. Takie zestawienia opierają się na podstawie rzeczownik + rzeczownik, co jednak w przekładzie znajduje swoje odpowiedniki w zestawieniu rzeczownik + przymiotnik (jako opis), np. 다세 대주택 [tasedae jutaek]-dom wielorodzinny.

Zawarte są także opisy podstawowych właściwości danego przedmiotu, co w przypadku budynków bądź pomieszczeń usługowych uwzględnia ich rodzaj:

()주택의 기본 명세:

아파트 경우:

아파트이외의 경우:

[juta eg-ui kibon myeongsae:

Apateu kyeong-u:

Apateu Iwui-ui kyeong-u:

[Tłum. literalne: podstawowa bazowa specyfika/opis:

Przypadek mieszkania:

Przypadek inny niż mieszkanie]

[TLOT: Podstawowy opis domu:

W przypadku mieszkania

W przypadku innym niż mieszkanie]

Także obszar, na którym ma zostać wybudowany dany obiekt będący celem dalszych ustaleń, zostaje jasno sprecyzowany i uwzględniony w dokumencie:

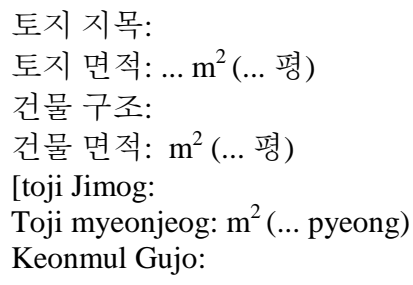


Emilia Wojtasik, Klauzula dotyczaca przedmiotu umowy najmu...

Keonmul myeonjeog: $\mathrm{m}^{2}$ (... pyeong)

[Tłum. lit.: kategoria ziemi:

Obszar ziemi: ... $\mathrm{m}^{2}$ (... pyeong)

Strunktura budynku:

Obszar budynku: ... $\mathrm{m}^{2}$ (... pyeong)]

[TLOT: Kategoria ziemi:

Powierzchnia ziemi: $\mathrm{m}^{2}$ (... pyeong)

Struktura budynku:

Powierzchnia budynku: $\mathrm{m}^{2}$ (... pyeong)]

Jak widać, w j. koreańskim ujmuje się takie dane przy pomocy zestawień rzeczownik + rzeczownik bez zbędnych w tym przypadku wykładników gramatycznych, np. 토지 면적 [toji myeonjeog] - powierzchnia ziemi.

W treści dokumentu, oprócz precyzyjnego opisu przedmiotu umowy, spotkać się można także $\mathrm{z}$ zapisami różnej treści, a regulującymi dalsze postępowanie, jak na przykład nie przedłużanie umowy.

() 임대차기간 만료 시 “갑”은 재계약을 체결치 않고, 임대차목적물의 매각을 원칙으로 한다.

[imdaechakigan mannyo si „kap”eun jaekyeyageul chegyeolchi ankko, imdaechamogjokmului maegageul weonchigeuro handa.]

[Tłum. literalne] W czasie zakończenia okresu najmu B nie podpisuje powtórnej umowy, ustala za regułę sprzedaż przedmiotu celu umowy najmu]

TLOT: W czasie zakończenia okresu najmu Wynajmujący nie podpisuje umowy ponownej ale przyjmuje za zasadę sprzedaż docelowego przedmiotu najmu.

W przytoczonym przykładzie ustalono, że zamiast kolejnego podpisywania umowy, przedmiot zostanie sprzedany. Pozwala to Najemcy obniżyć koszty ciągłej dzierżawy i ryzyko możliwości zerwania umowy. Użyto zwrotów opartych na zestawieniu rzeczownik + rzeczownik/+ konstrukcje gramatyczne, np. powtórna umowa 재계약 [jaegyeyag] - literalnie powtórne ustalenia, gdzie przedrostek 재 [jae] pełni funkcję powtarzalności, rzeczownik + konstrucja gramatyczna, np. 원칙으로 [weonchigeuro] - za zasadę, gdzie - 으로 $[\text { euro }]^{12}$ jest wykładnikiem oznaczającym tutaj jako, poprzez, a 원칙[weonchig] to zasada, reguła itp. Odwołano się także do zwrotu sprzedaz, gdzie zamiast najczęściej stosowanego słowa 판매 [panmae] - sprzedaż, użyto synonimu 매각[maegag], oznaczającego raczej wyprzedaż, a więc nacechowanego definitywnością.

W przytoczonych przykładach zaczerpniętych $\mathrm{z}$ umowów koreańskich przedmiot tej umowy (jeśli jest on ujęty w formie fizycznej) po jej rozwiązaniu bądź wygaśnięciu zostaje zwrócony Wynajmującemu. Jest to określone właściwymi zapisami. W przypadku najmu lokalu usługowego, spotkać się można m.in. z następującymi obwarowaniami:

제 11 조 (임대차 목적물의 명도)

${ }^{12}$ Patrz Im, Ho-Bin (2001: 154-157).

156 


\section{Comparative Legilinguistics 17/2014}

임대차기간의 만료, 계약의 해지, 해제 기타 사유로 인하여 이 계약이 종료된 때에는 “을”은 지체 없이 아래 각 호에 따라 임대차목적물 및 제반서류를 “갑”에게 명도 하여야 한다.

[je 11 jo (imdaecha mogjeogmului myeongdo)

imdaechakigaui mannyo, gyeyagui haeji, haeje kita sayuro inhayeo i gyeyagi jongnyodwen ddae-e-neun „Eul”eun jiche eopsi are kak hoe ttara imdaemokjeogmul mit jebanseoryureul „kap”ege myeongdohayeoya handa.

[tłum. Literalne: art. 11 (Zwolnienie przedmiotu celu umowy najmu)

W czasie, gdy umowa ta zostanie zakończona przez zakończenie czasu umowy najmu, rozwiązanie umowy, unieważnienie i inne przyczyny, B bez zbędnej zwłoki musi zwolnić/oddać A zgodnie z poniższymi punktami przedmiot celu umowy najmu i wszystkie dokumenty].

TLOT: W sytuacji zakończenia umowy spowodowanych zakończeniem okresu najmu, rozwiązaniem umowy, unieważnieniem i innymi przyczynami, Najemca musi niezwłocznie przekazać Wynajmującemu docelowy przedmiot umowy wraz $\mathrm{z}$ wszelkimi dokumentami zgodnie $\mathrm{z}$ poniższymi punktami.

Jak można zauważyć, ujęto sytuacje, które skutkują w różnoraki sposób zakończeniem umowy. Nowe elementy, wprowadzone do treści przytoczonego przykładu, to niezwłocznie, bez zbędnej zwtoki - 지체 없이[jiche eopsi] oparte na zestawieniu rzeczownik + przysłówkowa forma czasownika 없다 [eopta] - nie być. Wspomniany już kilkakrotnie docelowy przedmiot najmu - 임 대차목적물 [imdaechamogjeogmul] opiera się na zestawieniu trzech rzeczowników, z których ostatni jest traktowany jako podmiot a reszta stanowi jego opis. Fraza 제반서류 [jeban seoryu] - wszelkie dokumenty, literalnie wszystkie oficjalne dokumenty odnosi się do niewymienionych oddzielnie lecz odnoszących się do przedmiotu dzierżawy dokumentów. Zamiast czasownika przekazać, zastosowano tutaj czasownik o szerszym zakresie, mogącym odnosić się także do fizycznie wyrażonych przedmiotów - 명도하다[myeongdohada] - zwalniać, opuszczać. Oprócz standardowo wykorzystanych spójników, zauważyć daje się użycie bardziej oficjalnego i charakterystycznego dla języka urzędowego spójnika $i-$ 및 $[\mathrm{mit}]$.

Precyzować można także, co ma stać się z przedmiotem dzierżawy bądź najmu w przypadku, gdy Najemca nie rozliczy się z Wynajmującym ze zobowiązań finansowych. I tak:

() 2."을"이 이 계약 종료일로부터 3 일 이내에 임대차목적물 내에 있는 소유물을 반출치 않을 때에는 “갑”은 이에 대하여 적절한 조치를 취할 수 있으며 그 비용은 “을”이 부담하고, 조치 후 3 일이 경과하여도 “을”이 소유물에 관하여 하등의 조치를 취하지 않을 경우 “갑”은 임의로 매각 또는 기타의 방법으로 이를 처분하고 그 비용을 소요비용에 우선 충당할 수 있다.

[Eul-i i kyeyag jongnyoilluputeo 3il inaee imdaechamokjeogmul naee ittneun soyumuleul panchulchi aneul ttaeeneun ,kap"eun ie daehayeo jeogjeolhan jochireul chwihal su isseumyeo keu biyongeun ,eul"i pudamhago, jochi hu 3iri kyeonggwahayeodo ,eul"i soyumul-e gwanhayeo hadeug-ui jochireul chwihaji aneul kyeongu ,kap"eun imuiro maegak ttoneun kitaui pangpeobeuro ireul cheobunhago keu biyongeul soyobiyonge useon chundanghal su itta.

[Tłum. literalne: Jeśli B w ciągu 3 dni od zakończenia tej umowy nie opróżni używanych przedmiotów będących w przedmiocie celu najmu/dzierżawy, A może 
Emilia Wojtasik, Klauzula dotyczaca przedmiotu umowy najmu...

podjąć w związku z tym właściwe kroki i ten koszt obciąża B. W przypadku, gdy nie podejmuje żadnych kroków w związku z używanymi przedmiotami mimo upływu 3 dni, wtedy A według swojego uznania może metodą sprzedaży lub inną sprzedać ten przedmiot a ten koszt najpierw wlicza się i pokrywa kosztem używania. TLOT: W przypadku, gdy Najemca, w ciągu trzech dni od zakończenia umowy nie zwolni z używanych przedmiotów docelowego przedmiotu dzierżawy, wówczas Wynajmujący może podjąć stosowne kroki, a ów koszt obciąża Najemcę. Natomiast w przypadku gdy po podjęciu kroków pomimo upływu kolejnych 3 dni Najemca nie podejmuje żadnych kroków w związku z używanymi przedmiotami, Wynajmujący swobodnie może pozbyć się ich metodą sprzedaży lub inną a ów koszt zostaje wliczony i pokryty kosztami użytkowania.

Wprowadzone nowe słownictwo dotyczy kosztów, które ponosi jedna ze stron w związku z brakiem terminowego wywiązania się drugiej strony z poczynionych ustaleń. Przedmioty, które zostały na miejscu są ujęte frazą 소유물 [soyumul] - przedmioty używane/użytkowane, w połączeniu z konstrukcją gramatyczną oznaczającą $\mathrm{w}$ związku $\mathrm{z}$ - 에 관하여[-e gwanhayeo]. Ta z kolei stanowi składową wykładnika, użytego w tym kontekście $\mathrm{z}$-에[e] oraz czasownika 관하다 [gwanhada] - mieć zwiazek, dotyczyć (czegoś/kogoś), który tutaj oznacza synonimiczne 대하다[daehada] - wykazywać zwiazek z (czymś'/kimś) jednak wykazuje charakter bardziej oficjalny.

Wykorzystano także słownictwo odnoszące się do opróżniania, oczyszczania (tutaj: pomieszczenia) - 반출[banchul], co w słownictwie prawniczym powinno być ujmowane jako zwalnianie, opróżnianie. Zastosowano także frazę 조치를 취하다 [jochireul chwihada] - podejmować kroki, działania w połączeniu $\mathrm{z}$ potęgującym przekaz przymiotnikiem odczasownikowym (od czasownika deskryptywnego 적절하다 [jeogjeolhada] - być właściwym) - 적절한[jeogjeolhan] - właściwy, stosowny. Tę frazę zestawiono z konstrukcją modalną 르 수 있다 [eul su itta] - można coś wykonać.

(3) “을”이 이 계약 종료일 이후에도 임대차목적물을 명도하지 않을 때에는 계약종료일의 다음날로부터 명도한 날까지의 기간 동안 임대료와 관리비의 $150 \%$ 에 상당하는 금액을 불법점유에 대한 배상금으로 “갑”에 게 지급하여야 한다.

["eul"i i gyeyag jongnyoil ihuedo imdaechamogjeogmul-eul myeongdohaji anh-eul ddaeeneun gyeyagjonglyoil-ui daeumnal-lo-buteo myeongdohan nal-kkajiui gigan dong-an imdaeryowa gwanlibi-ui $150 \%$ e sangdanghaneun geum-aeg-eul bulbeobjeom-yue daehan baesang-geum-eulo "gab"ege jigeubhayeoya handa]

Tłum. literalne: W sytuacji gdy B pomimo upływu dnia zakończenia umowy nie przekaże przedmiotu celu najmu/dzierżawy, podczas okresu od dnia następnego do dnia zwolnienia musi zapłacić A jako odszkodowanie za bezprawne przetrzymanie kwotę obejmującą 150\% kosztów administracyjnych i czynszu.

TLOT: W przypadku, gdy Najemca nie zwolni przedmiotu najmu mimo zakończenia umowy, przez okres od dnia następnego po dniu zakończenia umowy do dnia zwolnienia, musi zapłacić Wynajmującemu w ramach odszkodowania za bezprawne przetrzymanie kwotę wynoszącą 150\% czynszu i kosztów administracyjnych. 


\section{Comparative Legilinguistics 17/2014}

Jak daje się zauważyć, klauzule odnoszące się do przedmiotów umów najmu są zbliżone w swojej treści do klauzul analogicznych w umowach skonstruowanych w języku polskim. Zauważalne są jednak różnice choćby w ujęciu administracyjnym adresów fizycznych nieruchomości, w opisach (także) technicznych urządzeń. Przede wszystkim różnice te dotyczą rzeczywistości prawnej, w jakiej funkcjonują umowy polskie i umowy koreańskie a także - co zrozumiałe - języka, którym operują.

\section{Podsumowanie}

Koreański język prawny i prawniczy od strony leksykalnej, a co za tym idzie także gramatycznej, ma wiele odniesień do języka chińskiego. Mówią o tym choćby Lee i Ramsey (2000: 135): "as a result, the Korean lexicon now contains three distinct layers of vocabulary: native, Sino-Korean, and English. These three layers give Korean, in some cases, three nearly synonymous words or expressions for what amounts to the same concept". Od strony samej struktury i konstrukcji prawa źródeł wiedzy należy szukać we wspomnianych już systemach japońskim, niemieckim i chińskim. To powoduje nie tylko zamęt i konfuzję wśród tłumaczy, ale przede wszystkim wśród odbiorców tekstów. Zauważalne są różnice językowe charakterystyczne dla tej dziedziny i odmiany języka specjalistycznego. Kielar (2013:114) podkreśla, że różnice te „w sposobie ujmowania rzeczywistości w kategoriach gramatycznych i leksykalnych przez różne społeczeństwa" tworzą i przekładają się „na konwencjonalny charakter każdego języka”. W przypadku języka koreańskiego, szczególnie w języku prawa i prawniczym widoczne jest rozdzielne użycie wyrażeń potocznych i ich minimalizacja użycia na rzecz korzystania z terminów bardziej wysublimowanych i sprecyzowanych. Odnosi się to w dużej mierze do zapożyczeń sinokoreańskich, których w języku koreańskim jest całkiem sporo - stanowią one około 60\% słownictwa (Sohn 2001: 89). Wiąże się to oczywiście z zakresem znaczenia osadzonym w rzeczywistości prawnej rozpatrywanych państw. Okazuje się zatem, że nie wystarczy znać termin administracja czy rodzina ${ }^{13} \mathrm{w}$ j. koreańskim lecz by tłumaczyć specjalistycznie konieczna jest znajomość ich odpowiednika socjo- lub idiolektycznego w ujęciu kodu społecznego (Grucza 1994 w Kielar 2013: 15) ${ }^{14}$ aby nie narazić się nie tylko na śmieszność i w konsekwencji utratę ciężko wypracowanej reputacji, ale $\mathrm{w}$ dalszej perspektywie także uniknięcia ewentualnych konsekwencji prawnych z tytułu błędnego bądź niefachowego wykonania zlecenia translatorskiego. Co więcej, konieczna jest znajomość rzeczywistości prawnej - tylko w taki sposób będziemy W stanie właściwie dobrać ekwiwalent dla np. sądu apelacyjnego, którego struktura terminologiczna dla niewprawnych tłumaczy może stanowić jeśli nie zagadkę to przynajmniej problem interpretacyjny. Wiedza o elementach wspólnych dla struktur niemieckich, japońskich czy chińskich będzie znacząca, ale niewystarczająca by właściwie posługiwać się językiem specjalistycznym. Stąd konieczność ciągłego doskonalenia swoich umiejętności i ciągłego pogłębiania wiedzy, do którego namawiają (jeśli wręcz nie przymuszają) nie tylko okoliczności i wymogi czasów, ale także zasada,

13 Przykładowo słownik koreańsko-koreański podaje rozróżnienie między standardowym a prawniczym terminem rodzina, podając odpowiednio słowa 가족 gajok $\mathrm{i}$ 가정 gajeong.

${ }^{14}$ Pisze o tym m.in. Barbara Kielar, formułując za F. Gruczą (1994) idiolekt jako ,język jako społeczny kod stanowiący własność określonej grupy lub społeczności” 
Emilia Wojtasik, Klauzula dotyczaca przedmiotu umowy najmu...

zawarta w Kodeksie Ttumacza Przysięgłego, do której tłumacze (nie tylko przysięgli) winni się odnosić:

„§ 7. Obowiązek doskonalenia kwalifikacji zawodowych.

Tłumacz przysięgły jest zobowiązany do stałego doskonalenia swoich kwalifikacji translatorskich, językowych i merytorycznych, w tym również podstawowej wiedzy w zakresie krajowego i międzynarodowego obrotu prawnego tłumaczonych dokumentów, zgodnie $\mathrm{z}$ obowiązkiem określonym w ustawie o zawodzie tłumacza przysięgłego."

Kielar (2013:113) idzie dalej, nazywając ciągłe poszukiwanie wiedzy w preferowanej przez tłumacza dziedzinie jako ,swoisty przywilej, sprzyjający ciągłemu rozwojowi intelektualnemu tłumacza". Zgodnie z tymi założeniami, artykuł ten niech posłuży jako punkt wyjściowy do dalszych, pogłębionych badań nad przekładem prawniczym polskokoreańskim i koreańsko-polskim.

\section{Bibliografia}

Delisle J. (et al., ed.) 1999, Translation Terminology. Amsterdam/Philadephia: John Benjamins Publishing Company.

Fabricius-Hansen, Cathrine, 2007, Paralleltext und Übersetzung in sprachwissenschaftlicher Sicht, W: Übersetzung, Translation, Traduction. Ein internationales Handbuch zur Übersetzungsforschung, red. H. Kittel et al., 322329. Berlin/New York: de Gruyter.

Grucza, Franciszek 1994, O jezzykach specjalistycznych (=technolektach) jako pewnych składnikach rzeczywistych języków ludzkich, W: Języki specjalistyczne, F. Grucza/ Z. Kozłowska (red.), 7-27. Warszawa: Wydawnictwo „Akapit”.

Hahm Pyong-Choon, 1967 i nast., The Korean political tradition and law, Seoul, Royal Asiatic Society Korea Branch.

Introduction to Korean Law, 2013, ed. Korea Legislation Research Institute, Springer Heidelberg-New York-Dordrecht-London.

Kim Kipyo, 2013. Overview. W: Introduction to Korean Law, 2013, ed. Korea Legislation Research Institute, Springer Heidelberg-New York-DordrechtLondon.

Im, Ho-Bin (ed.) 2001. Korean grammar for international learners. Yonsei University Press, Seoul.

Kaczmarek K., Matulewska A., 2010. Comparison of parallel texts of petitions in PolishHungarian and Polish-English translation. W: Across Languages and Cultures. Akadémiai Kiadó, Vol. 11, no. 1, June 2010, 67-81.

Kielar, B. 2013, Zarys translatoryki, Warszawa: Wydawnictwo Naukowe Instytutu Kulturologii i Lingwistyki Antropocentrycznej

Kierzkowska, Danuta. 2002. Ttumaczenie prawnicze, Warszawa: Translegis.

Kodeks Ttumacza Przysięgłego (http://www.tepis.org.pl/towarzystwo/ ktp.pdf, dostęp online 22.12.2013 r.)

Kubacki, A., 2008. Zestawienie niemieckich $i$ polskich ekwiwalentów nazw władzy sadowniczej W: Lingua Legis, marzec 2008, 52-67. 


\section{Comparative Legilinguistics 17/2014}

Kubacki, A., Wowro I., 2006, Europejskie modele ustanawiania tłumaczy przysięgłych oraz kryteria dopuszczające do wykonywania zawodu w wybranych krajach Unii Europejskiej, W: Rozwój lokalny $i$ regionalny po wejściu Polski do Unii Europejskiej Tom 2. (red.) A. Barcik i R. Barcik, 228-240, Bielsko Biała: Wydawnictwo Naukowe ATH, Bielsko Biała.

Lee Iksop, Ramsey Robert S., 2000, The Korean Language, SUNY Press, Seoul.

Matulewska, A. 2013. Legilinguistic Translatology. A Parametric Approach to Legal Translation. Linguistic Insights vol. 171. Bern: Peter Lang.

Matulewska, Aleksandra. 2007. Lingua Legis in Translation. Frankfurt am Main: Peter Lang GmbH.

Matulewska, Aleksandra. 2010. Teksty paralelne a ustalanie konotatów i denotatów na potrzeby przekładu polsko-angielskiego. W: Legilingwistyka porównawcza, Tom 3/2010, 57-69, Poznań: UAM.

Mo, Jongryn, Brady D.W. (ed.), 2010, The rule of Law in South Korea, Stanford: Hoover Institution Press,Stanford University.

Neubert A. 1996, Textlinguistics of Translation: The Textual Approach to Translation. In: Marilyn Gaddis Rose (ed.). Translation Horizons Beyond the Boundaries of Translation Spectrum. Translation Perspectives IX., 87-105. Binghamton: Center for Research in Translation.

Pieńkos, J. 2003, Podstawy przekładoznawstwa, Kraków.

Radwański, Z., 2005, Prawo cywilne - czesść ogólna. Warszawa: Beck.

Redelbach, A., 2002, Wstęp do prawoznawstwa, Toruń, Towarzystwo Naukowe Organizacji i Kierownictwa, Stowarzyszenie Wyższej Użyteczności „Dom Organizatora".

Šarčević, S. 2000. New Approach to Legal Translation. The Hague: Kluwer Law International.

Smith S. A. 1995, Culture Clash: Anglo-American Case Law and German Civil Law in Translation. Translation and the Law, Marshall Morris (ed.). 179-197, Amsterdam/Philadelphia: John Benjamins Publishing Company.

Sohn, Ho-Min, 1999, 2001. The Korean Language, Cambridge University Press, London.

Strona Słownika Koreańsko-Koreańskiego: http://krdic.naver.com 
Emilia Wojtasik, Klauzula dotyczaca przedmiotu umowy najmu... 